\title{
2 Right-wing populism, Euroscepticism, and neo-traditionalism in Central and Eastern Europe
}

\author{
Zdzisław Mach
}

\section{Introduction}

In recent years, the rapid development of nationalist movements in Central and Eastern Europe and the electoral successes of right-wing populist parties, especially in Hungary and Poland, have provoked not only concern among liberal-minded citizens but also questions regarding the reasons for the rise of populism and the factors responsible for it. Populism, and its right-wing variant, is certainly not unique to the Central and Eastern European region, as it is increasingly present in other parts of Europe, in America and elsewhere, but a closer look at its development in post-communist Europe may throw some light not only on the peculiarities of this region but may also help to better understand how populism functions in general.

There is a great deal of theoretical discussion on populism, and it is beyond the scope of this chapter to even provide an overview or summarise it. ${ }^{1}$ Here I will concentrate on right-wing populism, as it is widely present in post-communist Europe and very significantly informs the recent political developments there. It is also closely linked to the concept of nation and to the political application of tradition, which, I will argue, is at the heart of the Central/Eastern European version of Euroscepticism. ${ }^{2}$

\section{The construction of populism and ethnic nationalism in Central and Eastern Europe}

As it is generally shared in conceptual discussions on populism, its main feature is an opposition between 'the people' and 'elites', often expressed as 'we' and 'they'. In the right-wing version of populism, 'the people' equals 'the nation'. ${ }^{3}$ So the key question here concerns the meaning given to this particular concept, which has different significance in different historical and social traditions. The region of Central and Eastern Europe, largely because of its history, tends to understand the nation as a cultural, ethnic community, rather than a political, civic one. One of the main reasons for that is the modern history of the region, which used to be divided into multi-ethnic empires. Russia, Germany/Prussia and Austria (later Austro-Hungary), covered large 
territories inhabited by many ethnic communities, some of them having their own past of statehood and sovereignty, others developing a kind of ethnic nationalism in the process of modernisation, demanding sovereignty, independence and the right to become nations in the political, not only cultural sense. Ethnic nationalism constructs a cultural community separated by symbolic boundaries from others, those who do not belong to the nation even if they may happen to be citizens of the same state and inhabitants of the same town or village. An ethnic nation is ideologically constructed and presented as a 'natural' community, rooted in its territory, language, mythologised history, religion and tradition. ${ }^{4}$ National identity is then seen not as a matter of individual choice, but as a natural, obliging identification which people inherit and which is imposed on them by tradition, as a form of social belonging and as a moral duty.

If 'the people' equals 'our nation', then who is the elite? In general, elites are corrupted in the populist view of the world, alienated from the people by their own sense of superiority. They are those who hold power in all its dimensions, and who exploit the people. Elites are also presented as morally evil, decadent, alienated from the tradition of the people. This leads to a Manichean, dualistic model of the world, divided into good and evil, moral and corrupted, the exploited and the exploiters. ${ }^{5}$

In the populist discourse, identifying 'the people' with the ethnic nation means that all those who do not belong to 'us' are stigmatised as enemies of 'the people'. Such a construction opens the door for all sorts of exclusion. But it also means that 'the elite' are those who do not belong to the nation. This principle works in two ways: those who are excluded from the nation are declared to belong to the corrupt elite. Also, if someone is classified as a member of the elite, by the same token they are excluded from the national community, at least in the sense that they do not 'truly' belong to the nation; in reality they represent foreign interests and objectively act for the benefit of the national 'others'. As it is usually the case in such ideological, mythologised constructions, it does not really matter if the people in question can be convincingly included in this or that category by any 'objective' criteria of belonging to the nation or the elite. What matters is to which side they are classified by the populist constructors of reality.

In the countries of post-communist Central and Eastern Europe, which have been struggling for generations to gain national independence and political sovereignty, and whose national identities were constructed in opposition to the dominant nations identified with empires and other ethnic communities, such an exclusive, culture-based, ethnic model of nation appeals very strongly. Cultural, ethnic others, representing foreign values, may be presented as dangerous to the traditional moral and social order, as enemies of the nation. This applies not only to other nations, especially those which are seen as historical enemies, but also to all kinds of minority groups, ethnic, religious or sexual - everyone who is accused of trying to disturb the traditional national values or even to create an alternative to them. In recent years, such images 
were created for Muslim refugees or LGBT groups. In the right-wing populist discourse, 'the people' are identified with the national community of cultural tradition and traditional values, and in general are seen as a community of people who think alike. Such a nation is a moral community, one which is endangered in its integrity by corrupt elites which betray the national values and speak and act on behalf of (and in the interests of) the globalised, cosmopolitan liberals who wish to destroy traditional nations in order to dominate, oppress and exploit them.

Cosmopolitan individuals and minority groups are not the only candidates for the status of elites in the populist discourse. This role may also be played by international, supranational institutions and organisations, such as the World Bank or International Monetary Fund. For the populists of the region of Central and Eastern Europe, the role of the elite is often given to the European Union, which is presented as liberal, cosmopolitan, trying to destroy national traditions and national sovereignty in order to create a liberal, secular Europe, deprived of values, especially collectivistic ones, such as the church and family, which nationalists/populists consider to be sacred.

\section{The crises of the EU and the rise of populist Euroscepticism}

In recent years, the EU has suffered from a series of crises which have strengthened populist movements in European societies. The financial crisis undermined trust in the EU as a stable, strong basis for the economic prosperity of the whole Community. For the new member states of Central and Eastern Europe, even though they were not particularly strongly affected by the crisis, it caused serious damage to their, perhaps somehow naïve, image of the EU as a secure haven to which they had aspired for so many years. This decrease of trust encouraged populist movements to argue that the only secure frame which might guarantee economic development and prosperity would be the nation state under a strong national government.

The second crisis, that of predominantly North African refugees, turned out to be much more significant. The prospect of receiving large number of cultural 'others', stigmatised by a negative stereotype of Muslims as enemies of Christianity and the family, who are said to resist assimilation and who are dangerous potential terrorists, generated very strong resistance not only on the side of populist political powers in Central and Eastern Europe, but also among large segments of their populations, especially those who strongly identified with ethnic nationalism. To make things worse, from the point of view of nationalists/populists, the plan to relocate refugees to all EU member states came from the liberal, cosmopolitan elites of Brussels. For many people of Central and Eastern Europe, unused to the ideas and practices of multiculturalism and already suspicious of the intentions of EU elites regarding the traditional national cultures of their region, this was a strong factor in strengthening their support of populists. In the Polish case, the refugee crisis and the panic generated among many Poles by the populist ruling party prior 
to the parliamentary elections was a decisive factor in their victory. The populist ruling party in Poland stigmatised refugees as culturally alien, dangerous terrorists who were intent on destroying Christian civilisation. The state propaganda also dehumanised the refugees by presenting them as lacking such basic features of civilised people as the determination and courage to defend their families in Syria, and carrying and spreading infectious diseases and parasites. ${ }^{6}$

\section{EU elites as the populist 'others'}

European elites are particularly dangerous from the point of view of nationalist populists, as they create alternatives to traditional national values by proposing a cosmopolitan way of life which may seem attractive to many members of society who wish to reach higher levels of consumption and are tempted by the allegedly higher status of 'civilised Europeans'. For ethnic nationalists, any attempt to build a supranational identity, including a European one, is not acceptable, and is perceived as a threat to the national identity which is believed to be the natural and ultimate good, eternal and sacred. European elites are accused of trying to create and offer a European identity, and to weaken or even destroy the national identities of the societies of the EU. This European identity is criticised by ethnic nationalists for many reasons, also on the basis that there is no such thing as one European nation, especially if the ethnic understanding of the nation is applied. A cosmopolitan, multicultural, open concept of European identity is unacceptable for those who share the view that the only 'natural' community is based on a single cultural tradition in which commonly shared values are rooted. In addition to this, the European elites are presented in the nationalist/populist discourse as promotors of values which are incompatible with the cultural tradition of 'the people', often immoral and in conflict with the religious view of the world. Here, the most prominent argument points at three elements of the liberal system of values: multiculturalism, especially openness to Muslim immigrants, the reproductive rights of women, including the right to abortion, and gender equality in general. All three elements are seen as dangerous to the cultural tradition, religion and the 'natural' order of the world.

The idea of the nation and the nation state as the natural form of social organisation, a community of people who are united by their cultural tradition and who think alike, essentially precludes the acceptance of any alternative collective identity on the same or higher level. Ethnic nationalists do not approve of any attempt to build a civic nation, on the basis of citizenship and individual choice, any concept of a multi-ethnic or multicultural nation. But they also reject any idea of supranational organisation if it is to become more than an association of sovereign, independent nation states. In such a view, the EU should not become anything more than the Common Market, a free trade zone and a platform of economic cooperation. The EU is seen by 
ethnic nationalists as a frame within which nation states fight for power and gains, and any suggestion that there is or there should exist anything like a real European community, governed by the principles of solidarity and creating its own collective identity, is seen as an empty ideology, indeed nothing more than a facade behind which real egoistic national interests are hidden. Also, the EU elites are presented as a group of cynical bureaucrats who use their position to maintain power and secure privileges. The image here is quite simple and constitutes a perfect example of a populist perspective: there are the European peoples, European nations which have their cultural identities, their traditions and their interests, and there is the EU elite, which tries to impose a new form of collective identity on them and a lot of economic and legal restrictions in order to rule for their own gains.

\section{The EU as a 'cash machine'}

In the region of post-communist Central and Eastern Europe, among the new members of the EU there is another element determining the perception of the EU which should be taken into account. The EU is primarily seen as a platform for the redistribution of resources and an opportunity for the new members to overcome the legacy of communism and to close the gap between them and the West of Europe. This legacy, and this gap, is seen differently by different groups of Central and Eastern European societies. There are those for whom accession to the EU was seen as a chance to modernise, not only in the economic sense but also to build a modern, liberal democratic society, to overcome the post-communist mentality, to create an open, multicultural civil society, one which was more individualistic, free and liberal. EU membership was a chance to accomplish all this, to install mechanisms of change, democratic and market institutions, to change the law and to educate the societies for liberal democracy and the rule of law. But for populists/nationalists, the image of the EU is very different. The Union is seen as a hub of liberal, leftist ideas and values, which are in direct opposition to those promoted by them: national unity, collectivism, national tradition, especially in such sensitive areas as family and sexual morality, as well as traditionalistic religiosity. Moreover, the EU is seen as a supranational organisation which claims to have the right to interfere in the internal affairs of sovereign member states. In those countries of Central and Eastern Europe where populist nationalists are in power (Poland and Hungary), the governments are openly Eurosceptic and engage in serious conflicts with EU institutions, mainly over core EU values, such as human rights, free media and the rule of law. At the same time, their societies tend to support their country's membership of the EU and Poland has one of the highest levels of support amongst its populace in the whole Union. ${ }^{7}$ How can this paradox be explained? What is the reason for having a Eurosceptic government of a Euro-enthusiastic society?

The explanation is to be found in the nature of this popular Euro-enthusiasm. It is mainly based on the image of the EU as a generous donor, 
disseminating European funds among poorer members and helping them to close the economic gap between them and the more developed countries. The EU is accepted, liked and supported because it gives money. But in spite of this it is still seen as an external entity, a useful 'other', whom the people of Central and Eastern Europe wish to have as a financial 'sponsor', but with whom they do not share a common identity or sense of belonging. The dominant discourse in the media presents the EU as a frame within which money is distributed for the benefit of more deserving countries and regions. But the EU remains being presented as 'external' and a foreign body. Moreover, this European money, however useful, is not seen as a common European investment in a common future. Instead it is presented as a just redistribution from the rich to the poor, as a realisation of justice, and as rightful compensation for the decades of isolation and communist domination, which is blamed for the economic underdevelopment of the Central and Eastern European region. Following this logic, it is only just that the rich now share with the poor. But what does not come with this expectation is any sense of common identity, of a community of values to which the former communist Europe now belongs. The regions of Central and Eastern Europe happily receive the money but object to any conditions being specified by the European Commission. There must be no strings attached to the donation. The poor region deserves the money but does not accept any conditions as to how the money is to be used. Any such suggestions are seen as an unjustified intrusion in the sovereignty of the recipients. ${ }^{8}$ Such an attitude reveals the lack of any sense of belonging to the EU as a community of values; the Union is just seen, as it is often said by critics of such an approach, as a cash machine. Not surprisingly, nationalists/ populists of Central and Eastern Europe, when they speak about the future of Europe, prefer it to be reduced to nothing more than the Common Market. Any attempt to link the redistribution of funds within the EU to any form of solidarity other than financial (for example, the relocation of migrants) or the fulfilment of the principles of the rule of law is rejected as an attack on the sovereign rights of member states. European identity is totally absent from this perspective; the only identity that matters is the national one, linked to the ethnic model of nation.

\section{EU values and Euroscepticism}

When it comes to values, the gap between the populists/ethnic nationalists of Central and Eastern Europe and the EU institutions and their declared axiology is tremendous. In the eyes of the populists, the EU represents everything they reject and despise: secularism, modern values with their roots in the Enlightenment (individual freedom and equality of people), gender equality, the rights of minorities. The EU openly chose and stated in treaties individualistic values as its axiological foundation, while ethnic nationalists call for the inclusion of collectivistic values such as the church, the family and the nation in the EU documents, such as the Charter of Fundamental Rights and 
the Treaty of Lisbon. In effect, populists/nationalists position themselves in a sharp cultural and ideological contrast with the EU. This is the core of the process of 'othering' the EU, presenting it as an external, alien entity which may be pragmatically useful, but which is culturally foreign.

\section{'The heart of Europe is here'}

The negative view of the EU from the point of view of Eurosceptic populists/ nationalists does not mean that Europe as such is presented in its historical representation in an equally negative way. Populist leaders of Central and Eastern Europe eagerly identify with what they consider to be 'true' European values. The core of them is Christianity, but in the larger, broader sense also the cultural traditions of European nations, presented selectively to suit the current rhetorical needs of the populist ideological leaders. In Poland and Hungary this strategy takes the form of an image of the Central and Eastern European region as the place where true European values are still cherished and preserved, in contrast to the EU where they have been forgotten and eliminated by the leftist liberal leadership of the Union. The attempts to create a permanent coalition of Visegrad countries within the EU is not only a political strategy to build a stronger position to successfully fight for national interests, but it is also an identity construction of defenders of 'true' European values and traditions against those who betrayed them and who currently constitute the EU elite.

\section{Ontological security, populism and tradition}

How can one explain this illiberal turn and the rise of populism in the region of Central /Eastern Europe, which so obviously benefitted economically from the post-1989 transformation and its subsequent accession to the EU? Among the answers, one may point to the issue of security, in its broad, ontological sense. It is important to remember that although the region certainly developed economically during the 30 years of transformation, and successfully implemented the principles and mechanisms of liberal democracy and a market economy, not everybody in these societies benefitted equally from the post-communist changes. There has been a lot of accumulated bitterness and frustration, often in spite of objective economic indicators showing progress and growing levels of affluence. In the subjective view of many citizens their situation has not been significantly improved, especially in relative terms, in comparison to others who have been more successful.

Openness, which was so often mentioned as one of the most precious achievements of the 1989 changes in post-communist Europe, also proved to be ambiguous in its cultural consequences. For many educated people it was a value they had been longing for, while there were also others who experienced a kind of culture shock and perhaps they even constituted the majority. They were exposed to new ideas, to a pluralism of values and ways of life. Their 
experience before 1989 had been that of the homogeneity of a communistdominated society, with a single, state-controlled message from the censored public media and education, a very poor choice of consumer goods, and very little pluralism in the public sphere and public space. The everyday experience of the overwhelming majority of citizens was that of the cultural, symbolic and ideological monopoly of one programme, or (as in the Polish case with the powerful Catholic church in opposition to the regime), a kind of dualism of two dominating voices. But the experience of a pluralism of choices, which would require individual free decisions and responsibility for them, was not given to most people in the region. With the 1989 changes, new ideas came through the open door to society, and pluralism also brought a need to choose and to take one's life in one's hands with all the responsibility which freedom also created.

Ontological security is a psychological but also a social condition which may be caused by a rapid and radical change, such as migration, political transformation or changes in the economic environment, all of which disturb the stability of the (natural, social and cultural) environment and deprive people of their sense of being part of a stable, meaningful world. This is a traumatic experience which causes frustration, fear and anxiety, and may lead to violence. To reduce these negative experiences, people tend to search for a chance to recreate the sense of security and stability. ${ }^{9}$ They may do so individually or collectively, through their own autonomy and independence, forwardlooking activity and entrepreneurial actions, but they may also escape behind secure boundaries of tradition, which give them simple and definite answers to all questions. There may be many reasons why some people find it difficult to restore the sense of ontological, mental security through their own actions or in partnership with others. Much seems to depend here on subjective selfperception as well as 'objective' external conditions. Old age, unemployment, low education inadequate to the shifting requirements of the labour market, a dogmatic approach to the world which may be linked to traditional religiosity - these and other factors seem likely to produce a passive reaction to the loss of security, an inability to cope with it individually and constructively, to take the future into one's own hands and to assume responsibility. Escape to tradition may be a solution. In such a situation, people may also choose to follow a strong leader, one who guarantees security and releases them from the need to make difficult decisions. Authoritarian and populist political parties take advantage of this and supply a political offer to such a demand.

A return to tradition may be a solution for those unable to cope with the sense of insecurity. Freedom may be a burden, especially since it is connected to responsibility. People who for various reasons do not feel fit to respond individually to the challenge of change, look for a remedy in the form of collective identity based on tradition. Tradition appears in this process as an escape from freedom of choice and responsibility as a source of values and norms, often legitimised by religion, it defines 'us' as a community, answers questions regarding our collective identity, and provides a sense of belonging 
to the world where everything and everybody have their place - it may also help to identify 'the others', who represent a dangerous alternative to the traditional system - for example elites, immigrants or liberals.

Tradition has become an important subject of sociological research, not only of premodern societies but also in the context of reflections on the significance of heritage and the importance of the past for present developments. Jerzy Szacki and Edward Shils ${ }^{10}$ have devoted comprehensive studies to the concept of tradition as the presence of the past in contemporary society. It became clear that tradition is a very useful and powerful instrument which may be used in attempts to construct political and ideological images and to become an essential part of collective identity. The very influential book on the invention of tradition edited by Hobsbawm and Ranger ${ }^{11}$ shows some examples of such manipulation.

Traditionalism is a kind of policy aiming at a return to tradition in order to find the roots of culture, to get rid of unwanted elements of a way of life which were borrowed from or imposed by modern society. This movement is well known in the post-colonial world, where efforts are made to replace imposed, Western values and ways with the society's own, traditional ones, suppressed and forgotten, but now revived. ${ }^{12}$ In Europe, similar processes are taking place, with tradition becoming a point of reference in search of the authenticity of culture, while the political agenda behind it is to emphasise the contrast between the original, authentic culture of 'the people' and artificial Westernisation imposed by those who had power to do so.

For clarity of concepts, it may be advisable to make a distinction here between traditionalism, which means choosing traditional culture and values rather than their modern alternatives represented by globalisation and Western-oriented modernisation, and neo-traditionalism, which refers to a conscious, often politicised, return to tradition and the rejection of modern cultural patterns and values already widely present in the society. In this context, neo-traditionalism appears in the post-communist region of Europe as a strategy to escape from the unknown, alien and dangerous new values and ways of life which come from the EU to Central and Eastern Europe. To protect themselves from this danger, the populists/nationalists/traditionalists suggest that these societies should recreate their own tradition and with it the people's healthy and moral way of life and ontological security.

Neo-traditionalism appears here as a kind of collective identity - an image of meaningful actions which refer to tradition as a source of stable and legitimate values which explain the world in simple terms, describing problems in simple categories connected with value judgements, and restore the feeling of belonging to a stable and secure community. Neo-traditionalism is also a political strategy against those who propose deeper integration with the Western world, and in particular with the EU, in the name of modernisation. Traditional values and ways of life are thus presented as a healthy alternative to liberal individualism, which restores security and dignity based on tradition and builds a more authentic collective identity rooted in tradition, 
ethnicity and sound moral principles. As such, neo-traditionalism may be a strategy chosen by populists who propose the strengthening of a healthy, culture-based nation and moving away from the decadent, liberal West, which has been chosen by the corrupt cosmopolitan elites.

\section{Notes}

1 Among the tremendous body of literature on populism, I mainly refer here to the following works: Cas Mudde, Populist Radical Right Parties in Europe, (Cambridge University Press 2007); Andrea LP Pirro, The Populist Radical Right in Central and Eastern Europe: Ideology, Impact, and Electoral Performance, (Routledge 2015); Lenka Bustikova and Petra Guasti, 'The Illiberal Turn or Swerve in Central Europe?', (2017), 5, Politics and Governance, 4, 166; Cas Mudde and Cristobal Rovira Kaltwasser, Populism: A Very Short Introduction, (Oxford University Press 2017); Rogers Brubaker, 'Why Populism?', (2017), 46, Theory and Society, 357385; Cristobal Rovira Kaltwasser, Paul Taggart, Paulina Ochoa Espejo, Pierre Ostiguy, The Oxford Handbook of Populism, (Oxford University Press 2017).

2 Radoslaw Markowski, 'Populism and Nationalism in CEE: Two of a Perfect Pair?' in Alberto Martinelli (ed), When Populism Meets Nationalism. Reflections on Parties in Power (ISPI Report 2018), 71-94; Natasza Styczyńska, 'Eurosceptic Parties in the Central and Eastern European Countries: A Comparative Case Study of Poland, Hungary and Bulgaria' in Benjamin Leruth, Nicholas Startin, Simon Usherwood (eds), The Routledge Handbook of Euroscepticism, (Routledge 2018), 139-154.

3 Cas Mudde, Populist Radical Right Parties in Europe, (Cambridge University Press 2007).

4 See Anthony D Smith, The Ethnic Origins of Nations, (Oxford Blackwell 1986); Anthony D Smith, Nationalism, (Cambridge Polity 2001).

5 Ben Stanley 'The Thin Ideology of Populism', (2008), 13, Journal of Political Ideologies, 1, 103; Cas Mudde and Cristobal Rovira Kaltwasser, Populism: A Very Short Introduction, (Oxford University Press 2017), 11-12.

6 See speech by Jarosław Kaczyński in Maków Mazowiecki, October 2015, available at https://tvn24.pl/wideo/z-anteny/komisja-europejska-wystapi-do-tsueo-zawieszenie-izby-dyscyplinarnej,1915241.html?playlist_id=31421 accessed 20 September 2020.

7 In February 2020 89\% of Poles expressed support for Poland's membership in the EU. CEBOS Komunikat z badań, (2020), 32, ISSN, 2353-5822.

8 See Zdzisław Mach (ed) Local Community, Power and European Integration, (Peter Lang 2017).

9 Zygmunt Bauman, Liquid Times: Living in an Age of Uncertainty, (Cambridge Polity 2006).

10 Jerzy Szacki, Tradycja. Przeglad Problematyki, (Poland Państwowe Wydawnictwo Naukowe 1971); Edward Shils, Tradition, (The University of Chicago Press 1981).

11 Eric Hobsbawm and Terrence Ranger (eds), The Invention of Tradition, (Cambridge University Press 1983).

12 See for example Vladimir Braginsky, The Comparative Study of Traditional Asian Literatures. From Reflective Traditionalism to Neo-traditionalism, (Routledge 2004). 